\title{
Italian Studies: An Interdisciplinary Perspective
}

Clodagh Brook (Trinity College Dublin)

\section{c.j.brook.1@bham.ac.uk}

Florian Mussgnug (UCL)

f.mussgnug@ucl.ac.uk

Giuliana Pieri (Royal Holloway University of London)

g.pieri@rhul.ac.uk

Italian Studies researchers today find themselves at a unique historical vantage point as a result of gains in interdisciplinary methodologies and perspectives and the embracing of cultural studies by modern language disciplines. This has led to a questioning of what 'Italian Studies' is, but also to the broadening of the object of study and to the opening up of new interdisciplinary perspectives on the arts, recuperating art objects which have been lost in the gaps between disciplinary areas, and redefining the worth of one art for another. In this article, we argue that there has been a paradigm shift towards interartistic and intermedial methodologies in twentieth and twenty-first century artistic practice in Italy, and that critical inquiry within Universities is beginning to catch up, albeit slowly. In the first half of our article, we map some recent trends in cultural, visual and comparative studies and explore the influence of these fields on the development and future of Italian Studies. In the second and final part, we draw attention to three periods in twentieth and twenty-first century Italian culture that have been especially marked by interartistic experimentation, but which, we claim, have been most often viewed through a traditional, disciplinary lense. By suggesting alternative critical approaches to Futurism, the early postmodernism of the neoavanguardia, and, finally, digital experimentation, we highlight the importance of interdisciplinary research, and argue that the attention to interartistic and intermedial research will be vital to our discipline as it develops over the next decade. We also present some continuing research gaps that our discipline may wish to consider over the coming years. The perspectives we lay out in this article were developed during 
the first phase of the AHRC-funded Interdisciplinary Italy project, Interdisciplinary Italy 1900-2015: Art,

Music Text. ${ }^{1}$

\section{Why are we doing interdisciplinary research now?}

Before exploring how the interdisciplinary paradigm shift affects Italian Studies, we first wish to sketch the reasons for this intellectual shift more broadly. We are at a unique juncture in the history of academic pursuit. Cultural Studies and transnational perspectives have opened up the scholarly field and encouraged a move away from mono-disciplinary, nation-bound modes of enquiry towards a stronger interest in studying patterns of connectivity. Moving between disciplinary, artistic and medial boundaries is now common and has strong institutional backing. Over the past decade, UK research councils have played an important role in championing the case of interdisciplinary research. Whilst many scholars and funding bodies have embraced this widening of the field, it is not uncommon to come across the perception that interdisciplinarity has become the dominant discourse. Whilst interdisciplinarity as a methodological approach remains undertheorised, its perceived normativity is felt by some as a potential threat to monodisciplinary research, leading to a loss of disciplinary expertise.

At this juncture a series of transformations in thinking combine, in a Foucauldian web, to allocate power to a growing interdisciplinary agenda. Summarising the vast literature on interdisciplinarity, three key causes for the current developments in interdisciplinarity can be said to emerge. The first of these is the desire to

\footnotetext{
${ }^{1}$ The first phase of Interdisciplinary Italy ran from July 2012 to June 2014; Clodagh Brook and Giuliana Pieri were Principal Investigator and Co-Investigator respectively, and Florian Mussgnug, who had been involved in the project's planning phase, joined them on the steering committee. We thank everybody who contributed so generously and enthusiastically to the project, especially those on the project's Advisory Board, all those who joined the discussions at the three workshops in Rome (Roma Tre), New York (NYU and Casa Italiana) and London (UCL), and who contributed to the panels at the Society for Italian Studies Biennial Conference at Durham (2013). The networking phase of the project focussed on key periods (modernism, postmodernism and the contemporary digital age) and aimed to provide a forum for discussion of the root causes and development of modern and contemporary interdisciplinarity practice in Italy, especially with regard to the crossing of the borders between the arts and media. The project also encouraged discussion of questions centred on the place of interdisciplinarity in transforming research and teaching in Italian Studies and Modern Languages in universities and schools, and how this could be used to strengthen our discipline's public engagement profile with museums, artists and schools. Since then, the project has entered its second phase, Interdisciplinary Italy 1900-2020: Interart/Intermedia, also funded by the AHRC. Supported by the Senior Research Fellow, Emanuela Patti, this second phase will result in three book publications, workshops, an exhibition, conference, and public events.
} 
grasp totality, the desire to see things from all angles in order to better understand a whole. This is a desire that has always been with us, as Julie Thompson Klein argues, and spans ancient Greek philosophy, the medieval Christian summa, the Enlightenment ambition of universal reason, the Unity of Science movement, to name but a few. ${ }^{2}$ This encyclopaedic desire to grasp the totality of the thing from all angles is of course at odds with any academic segregation of disciplines. It demonstrates a will to go beyond the boundaries of one discipline, which is then seen as too narrow and too specialist to enable academics to talk to people outside one's field, and thereby rendering one's research more relevant to those outside the academe. One reason why this desire to grasp totality has gained particular favour in recent years is clearly that, being aligned to the discourse of the generalist and enabling scholars to talk meaningfully to the public and the layman and not just to the specialist, interdisciplinarity has become aligned with the current impact agenda in the UK that is supported by all national funding bodies. Interdisciplinarity fits, in other words, with the imperative currently upheld by universities in the UK, and increasingly elsewhere, to demonstrate their relevance to the wider world. Politically, therefore, it has institutional support. While the recent upsurge in interdisciplinarity can be seen as a contemporary feature of academic life, linked to impact, it is worth remembering that it is a deep-rooted desire which can also be seen as a return to a practice that has been seen little within universities since the early 1800 s when university disciplines, as we know them today, began to emerge and slowly become self-referential and closed, developing specialist journals, approaches and terminologies.

The second cause of the current academic focus on interdisciplinary methodologies emerges from a postmodern challenge to authority, hierarchy and canon, representing a 'sacred edge in the reopened battle over inclusion and exclusion', according to Douglas Bennett. ${ }^{3}$ Interdisciplinary work, Roland Barthes tells us, is not a peaceful operation: it begins effectively, he notes 'when the solidarity of the old disciplines

\footnotetext{
2 Julie Thompson Klein, 'A Taxonomy of Interdisciplinarity', in Robert Frodeman, Julie Thompson Klein, and Carl Mitcham, The Oxford Handbook of Interdisciplinarity (Oxford: Oxford University Press, 2010), pp. 15-30.

${ }^{3}$ Douglas Bennett, 'Innovation in the Liberal Arts and Sciences', in Education and Democracy: Re-imagining Liberal Learning in America', ed. by R. Orrill (New York: College Board, 1997), pp. 131-49 (p. 144).
} 
breaks down, a process made more violent, perhaps by the jolts of fashion to the benefit of a new object and a new language, neither of which is the domain of those branches of knowledge that one calmly sought to confront' ${ }^{4}$ As the world is clearly not actually divided up along disciplinary lines, those lines can be disputed and re-drawn, and, according to Giles Gunn, 'the inevitable result of much interdisciplinary study, if not its ostensible purpose, is to dispute and disorder conventional understandings of relations between such things as origins and terminous, centre and periphery, focus and margin, inside and outside' ${ }^{5}$ Interdisciplinarity therefore arises not just from an idealistic desire for totality, but, almost paradoxically, also from a sceptical loss of confidence in modes and concepts, and from a postmodern experimental attempt to rethink common categories, unfixing boundaries that conceal domination or authority. The rise of cultural studies, too, can be seen as part of the postmodern concern with inclusion and exclusion, and the unpicking of hierarchy and canon.

Finally, it is clear that objects of study have themselves become increasingly hybrid over the course of the last century and this has compelled academics to find new ways of talking about these. A book, a painting, a building: none of these are watertight objects which contain no trace of elements beyond themselves. Influence is not an impermeable system whereby a writer is influenced only by other writers, or a musician only by other musicians, a truism evidenced by the example of Edoardo Sanguineti who claimed that the inspiration for his first collection of poetry, Laborintus (1956) was, for instance, the composer Arnold Schoenberg, and by the example of filmmaker, Marco Bellocchio, who recognises that he was influenced by both opera and theatre. Creative people do not necessarily make the artistic distinctions that academic scholars do. However, it is not just a question of influence: many art forms are not singular, like a book or a painting, but are hybrid. There are hybrid forms of art that have been around for centuries or even millennia, such as graffiti as text-image; collages; opera as text and music; theatre as performance and text.

\footnotetext{
${ }^{4}$ Roland Barthes, 'From Work to Text', in Textual Strategies, ed. by Josue V. Harari (Ithaca, NY: Cornell University Press, 1979), pp. 73-81 (p. 73).

${ }^{5}$ Giles Gunn, 'Interdisciplinary Studies', in Introduction to Scholarship in Modern Languages and Literatures, ed. by Joseph Gibaldi (New York: Modern Language Association of America: 1992), pp. 239-61.
} 
However, in twentieth and twenty-first century Italy, hybrid genres and art forms have seen a rapid expansion. From the last years of the nineteenth century when cinema emerged, itself a hybrid practice, to the growth of performance art (art, literary expression, music, theatrical performance), from the computergenerated poetry of the 1960s, to the post-Internet developments, such as blogs and the cellphone novel, digital visual poetry, and sound art, there has been an explosion of new hybrid genres and artistic forms. Henry Jenkin's celebrated book Convergence Culture: Where Old and New Media Collide ${ }^{6}$ is perhaps the keystone of the current debate on hybridity: it specifically explores the merging of traditional and new media, and the resulting explosion of new forms of creativity at the intersections of various media technologies. This is not a merging into one single form of media, one single device on which we do everything; after all, Jenkins argues that 'there will never be one black box controlling all media', ${ }^{7}$ but a fragmentation into many different hybrid and blended forms available on a variety of platforms as a result of, in large part, digitization.

The steady shift across the twentieth and twenty-first century towards ever more evident interdisciplinary and interartistic practices must be seen in terms of the embedding with Italian, and Western society more generally, of a whole host of linked ideas: pluralisation, experimentation, fragmentation, loosening of hierarchies, border crossing, and holistic viewpoints, that were all slowly emerging across the arc of the twentieth century. We can also associate these practices, however, with pessimism with regard to the efficacy of the individual arts to express: a concern, which while longstanding, emerged particularly strongly under modernism. So, it is both an embracing of an idealistic, even utopian, vision of a holistic, nonhierarchical and democratic society, but also an acknowledgement of an impoverishment of any single artistic tool to reflect meaning.

\footnotetext{
${ }^{6}$ Henry Jenkins, Convergence Culture: Where Old and New Media Collide (New York: New York University Press, 2008)

${ }^{7}$ Henry Jenkins, 'Convergence? I diverge', MIT Technology Review (June 2001)

<http://www.technologyreview.com/article/401042/convergence-i-diverge/> [accessed 14 Dec 2014]
} 


\section{Italian Studies becomes Interdisciplinary? Cultural Studies, the Visual Turn and Comparative Literature}

If the rise of interdisciplinarity is the result of a Foucauldian network of pressures - from the quest for totality (given impetus by its institutional underpinning in the UK's impact agenda), to a postmodern dissent regarding categories and hierarchies, to the increasingly unstable and hybrid objects of study what are the effects on the early conceptualization and development of the discipline of Italian Studies? A diachronic overview of the early years of the discipline enables us to track shifting disciplinary alliances and to reflect upon the changing shape and scope of scholarly enquiry in Italian Studies. Surveying the Italian Studies journal, which was the discipline's key intellectual output at that time, provides us with a snapshot of what was deemed worthy of interest in the discipline's early years. Cecil Grayson's 1961 Index to the preceding volumes offers an overview of the journal's focus from its launch in 1935 . The vast majority of the articles (sixty-one in total), as David Robey notes, are detailed, often minute treatments of topics in literary, cultural and textual history from the beginnings to the $19^{\text {th }}$ century; ${ }^{8}$ twenty-nine detail past literary connections between Italy and Britain; nine focus on art history; two tackle linguistics and just one engages with music. The Italian Studies journal simply published no articles before 1961 on cinema, on radio, on television, on dance or on fashion. In other words, the study of the arts was narrow and limited in large part to 'high literature' and 'high art', mainly painting and sculpture. In addition, articles before the 1960s lacked much real interdisciplinary research: in other words, literature was not treated alongside other arts, but separate from it, so that when the journal's discourse went beyond literature, its methodologies were largely multidisciplinary, rather than interdisciplinary, presenting discrete articles on architecture or opera or paintings. Of note, too, is the absence of disciplines beyond literature, art and history: there is a pointed lack of articles, for example, on education, science, design, and contemporary politics.

\section{Cultural Studies}

\footnotetext{
${ }^{8}$ David Robey, 'Italian Studies: The First Half', Italian Studies, 67.2 (2012), 287-99.
} 
The development of the discipline since the early years, captured in Grayson's 1961 Index, has been rather intriguing. In the decades after the Index, the overwhelming majority of articles in Italian Studies continue to focus on literature and history, with only a handful dedicated to art, architecture, linguistics, music, theatre, ${ }^{9}$ and few which are genuinely interdisciplinary. A striking revolution in practice, however, takes place over just a few years after the new millennium, as cultural studies embeds itself into the discipline, just as it does co-temporaneously in other Modern Languages disciplines. Thematic approaches often, but not exclusively, dealing with contemporary material began to emerge in the special issues on gender (2005), on Italy and its colonies (2006), film (2007), and on textual transmission (2008). While the first Special Issue on gender is entirely textually orientated, the subsequent special issues shift the focus from literary texts, broadening the discipline to firmly incorporate cinema, media, pedagogy, politics and the social sciences. The launch of the first annual Cultural Studies issue in 2010 , more than a decade after the publication of Italian Cultural Studies: An Introduction ${ }^{10}$ and more than half a century after discussions of cultural studies first began, signals a turning point and crystallises the transformation of the field. However, the late arrival of cultural studies into Italian Studies also points to resistance within our field to this approach, and was not without its critics, as reflected in the Issue's first editorial in which Derek Duncan the editor - feels the need to justify the engagement with 'an admittedly ill-defined, and perhaps still controversial area', and points out the sub-disciplinary difficulty of defining the boundaries of Italian Cultural Studies. ${ }^{11}$

In the first issue of Italian Studies: Cultural Studies, attention to social questions takes precedent over attention to texts, and social questions are now applied across a range of different texts, events, cultural productions, and institutions (private letters, academies, general cultural production, film, architecture, journalism). Literature falls into a minority position, as just one cultural product among many. The

\footnotetext{
${ }^{9}$ Between 1961 and 1999, 266 articles were published in Italian Studies. Of these 213 dealt with literature, 239 treated literature and history, 19 were on art and architecture, 8 on theatre (largely from a textual, rather than performance, perspective), 8 on music (also typically on text rather than performance), 9 on linguistics, 7 on philosophy or cultural theories, 2 on media, 2 on cinema, and 1 was on then-contemporary politics.

${ }^{10}$ Italian Cultural Studies: An Introduction, ed. by D. Forgacs and R. Lumley (Oxford: Oxford University Press, 1996).

${ }^{11}$ See Italian Studies, 65.3 (2010), 308-09.
} 
transformation is embedded in the shift between the two dedicated gender studies issues of the journal, one published in 2005 and the second in 2010. While the first deals entirely with literary texts, the subsequent issue presents articles on lesbian social groups, documentaries, critical approaches and masculinity, in which texts, especially literary ones, are decidedly secondary. The broadening out takes place over the same period through a series of other journals like the Italianist and Italian Culture.

Nevertheless, the progressive introduction of Cultural Studies, with its turning point in 2010, does not result in the overhauling of the shape of the discipline. As Italian Studies shifts, it is clear that some areas within it grow, while others wither. While literature loses its dominant status, cinema studies has developed apace, especially since the first article to deal with cinema was published in Italian Studies in 1997. ${ }^{12}$ While History of Art may have lost its footing, studies of television have begun to grow. What emerges as artistic disciplines wax and wane, however, is that cultural studies and the rise of multidisciplinary and interdisciplinary approaches, rooted in thematically based research, are intimately linked.

\section{Visual Arts}

David Robey's review of the character and development of the discipline of Italian Studies in the UK through Italian Studies is not only an interesting attempt to historicize and systematize the discipline and its practitioners in the 'first half' of the journal's life, between 1937 and 1974. It has the added benefit of putting in sharper relief the place of a discipline which now normally sits outside the boundaries of Italian Studies after undergoing a radical reshaping over the past three decades: art history and the study of the visual arts in Italy. Extending the overview to the entire life of the journal, between 1937 and 2017 it is possible to note a marked change. The journal has had in its history only three long-serving art historians

\footnotetext{
12 The first article on cinema in Italian Studies in the UK was published in the first issue of The Italianist (1981). However, it was only after 1997, when Italian Studies opened its doors to cinema, that the field really showed signs of growth, and this growth was consolidated in 2003 when Modern Italy published its first article on film. Since then publishing on cinema has burgeoned, to the extent that in the US, a new journal dedicated to the field, Italian Cinema and Media was launched in 2012.
} 
on its editorial board: Anthony Blunt, between 1948-1951 when Blunt was also Director of the Courtauld Institute; E.K. Waterhouse 1951-61; and Francis Haskell, who served between 1961-1989 and was not replaced, signalling what appears to be a conscious move away from the comparative and interartistic dimension which, in the postwar period, saw a number of contributions by often eminent British art historians in the pages of the journal. After 1989, with no art historians on the editorial board, the relative place of the study of the visual arts decreased sharply with only four articles published between 1993 and $2001 .^{13}$

Whilst it might be tempting to link the waning of more traditionally conceived art historical studies from the journal to the steady growth and increasingly professionalization of cultural studies and the study of Italian cinema in particular, the vast majority of publications before and after the departure of art historians from the editorial board of Italian Studies still focused on the literary culture of Italy. In other words, art history was not ousted in favour of cinema or mass media, but what one witnessed at the time is a more general disappearance of the study of visual material from the journal, which seemed to reassert itself, together with the discipline it represented, as the domain of the study of Italian written, preferably literary texts.

The relative presence and/or absence of the study of the visual culture of Italy can be linked to a set of debates that, since the 1990s, have changed, often profoundly, the discipline of art history, opening up the still-debated fields of Visual Culture and Visual Cultural Studies and ushering in the so-called New Art History. In 1996, the journal October published what has come to be viewed as a watershed in the field of Visual Studies: the questionnaire on visual culture. ${ }^{14}$ The debate around the new disciplinary field

\footnotetext{
${ }^{13}$ Peter Armour, 'Michelangelo's Moses: A Text in Stone', Italian Studies, 48 (1993), 18-43, and 'The Prisoner and the Veil: The Symbolism of Michelangelo's Tomb of Julius II', Italian Studies, 49 (1994), 40-69. Emma Spina Barelli, 'Iconologia e provenienza dell'amorino di Donatello', Italian Studies, 51 (1996), 44-57. Helen Glanville, 'Veracity, Verisimilitude, and Optics in Painting in Italy at the Turn of the Seventeenth Century', Italian Studies, 56 (2001), 30-56. ${ }^{14}$ Svetlana Alpers, Emily Apter, Carol Armstrong, Susan Buck-Morss, Tom Conley, Jonathan Crary, Thomas Crow, Tom Gunning, Michael Ann Holly, Martin Jay, Thomas Dacosta Kaufmann, Silvia Kolbowski, Sylvia Lavin, Stephen Melville, Helen Molesworth, Keith Moxey, D. N. Rodowick, Geoff Waite and Christopher Wood, 'Visual Studies Questionnaires', October, 77 (Summer, 1996), 25-70.
} 
prompted the publication, in a short succession of time, of studies that provided a first official mapping of the research/disciplinary field that both established its academic pedigree and provided a number of key theoretical leads. ${ }^{15}$ Theo van Leeuwen and Carey Jewitt acknowledged the centrality of these earlier publications, whilst presenting the study of visual culture as a branch of the inherently interdisciplinary field of Cultural Studies, 'a specific sub-field of visual cultural studies' (p. 2) concerned in particular with the study of mass media and photography. ${ }^{16}$ In the same volume Martin Lister and Liz Wells discussed the attempts to define a specific field of Visual Cultural Studies which is not seen as a mere specialized subdivision of Cultural and Media Studies, 'but as a reworking of the whole field of concern', (p. 62), linked in their view to the proliferation of visual technologies in the late $20^{\text {th }}$ century). ${ }^{17}$

The most robust forum of theoretical debate in the field has been provided by the Journal of Visual Culture (JVC) In the editorial of the first issue, published on April 1 2002, the journal, on the strength of three decades of research and writing on visual culture, positioned itself as a 'site for interdisciplinary work', addressing the perceived need to focus on a number of 'explicitly visual domains', i.e. 'art, design, and architectural history, film, media, and television studies, photography, new media, and electronic imaging', whilst also drawing on areas which are less obviously visual such as cultural studies and critical theory, philosophy, history, geography/urban studies, and comparative literature with contributions from the major theorists of Visual Studies: Mieke Bal; James Elkins; Martin Jay; W.J.T. Mitchell. ${ }^{18}$ One of the most interesting aspects of the journal is that it was, especially in its early days, a site for vigorous and often contradictory debates over the Visual Studies and Visual Culture disciplinary fields. For instance, in the first issue James Elkins thought it would be helpful to define the field in terms of what it studies and posited

\footnotetext{
${ }^{15}$ Nicholas Mirzoeff ed., The Visual Culture Reader (New York: Routledge, 1998); Nicholas Mirzoeff, An Introduction to Visual Culture (New York: Routledge, 1999); and Jessica Evans, and Stuart Hall, eds, Visual Culture Reader (London: Sage, 1999).

${ }^{16}$ Theo van Leeuwen and Carey Jewitt, Handbook of Visual Analysis (London: Sage, 2002), especially, T. van Leeuwen and C. Jewitt, 'Introduction', pp. 1-9.

${ }^{17}$ Martin Lister and Liz Wells, 'Seeing beyond Belief: Cultural Studies as an Approach to Analysing the Visual', in Handbook of Visual Analysis, pp. 61-91.

${ }^{18}$ W.J.T. Mitchell, Iconology (Chicago: University of Chicago Press, 1987); Picture Theory (Chicago: University of Chicago Press, 1994); and 'What is Visual Culture?', in Meaning in the Visual Arts: Views from the Outside: $A$ Centennial Commemoration of Erwin Panofsky (1892-1968), ed. by Irving Lavin (Princeton, NJ: Princeton Institute for Advanced Study, 1995), pp. 207-17.
} 
that 'visual studies is predominantly about film, photography, advertising, video and the internet. It is primarily not about painting, sculpture or architecture, and it is rarely about any media before 1950 except early film and photography', (p. 94). ${ }^{19}$ This was in stark opposition to what Nicholas Mirzoeff had called for, i.e. a separate field of study able to go from 'oil painting to the internet' (Mirzoeff, 1998: 3) which was not simply a study of images but also of the centrality of vision in our lives.

An overview of the JVC does show one very conspicuous absence: there are no specific articles on Italian visual culture..$^{20}$ An observation by Lee Rodney (in JVC, 2006, no. 5, pp. 427-30) may provide an important suggestion as to the peculiar disengagement of Italian Studies from the Visual Culture debate and the relative dearth of studies within the more broadly conceived field of Italian visual cultural studies. Rodney reflected on the institutional politics that shaped the programmes of visual culture in the US and noted that: 'if art history has its origins in Italian, French and German sources, visual culture [...] is a product of Anglo-American discourse alone. While this may be partially true, some mention of this bias might help shed light on visual culture's relationship to the academic and institutional structures that have given rise to the new discourse', (p. 429). This may partially explain what appears as a double bias: Italian scholars (both Italianists and art historians) seem reluctant overall to engage with this field, whilst scholars of visual culture betray a bias against the visual culture of Italy which is still associated with the old art history rather than its new variety.

\section{Transnational literary studies}

In literary studies, there has been a marked shift towards transnational and comparative concerns. ${ }^{21}$ Since the beginning of the new millennium, comparative literature - now widely perceived as a disciplinary

\footnotetext{
19 James Elkins, 'Preface to the Book A Skeptical Introduction to Visual Culture', JVC, 1.1 (2002), 93-99.

20 The exception is a review by Mieke Bal, 'The Genius of Rome: Putting Things Together', JVC, 1.1 (2002), 25-45, which takes as its starting point the exhibition The Genius of Rome: 1592-1623 (London, Royal Academy; Rome, Palazzo Venezia, 2001), and an article by Jennifer Fay on Andre Bazin's interpretation of De Sica's Umberto D: J. Fay, 'Seeing/Loving Animals: André Bazin's Posthumanism', JVC, 7.1 (2008), 41-64.

${ }^{21}$ See Paul Jay, Global Matters: The Transnational Turn in Literary Studies (Ithaca, NY: Cornell University Press, 2010); Theo D'haen, The Routledge Concise History of World Literature (London; New York: Routledge, 2012).
} 
rallying point of literary criticism and the academic humanities - has gained increasing influence, also within Italian Studies. ${ }^{22}$ Across the UK and beyond, literary scholars have felt the pressures of cultural globalization, which is seen by many as a threat to the study of national literatures, but also as an opportunity to re-think and develop disciplinary agendas. Intellectual debates have widened in response to the demands of a fast-changing world, marked by the rise of the 'global South' and the shifting of centres of power to Asia. Research initiatives in the comparative humanities have sought to recalibrate the canon of world literature from diverse geographical and cultural angles, while also foregrounding collaborative research, translation studies, and new media. ${ }^{23}$ In Italian Studies, greater attention has been paid to minorities and migration, to re-thinking Europe's internal and external boundaries, and to assessing Italy's changing role in the world. ${ }^{24}$ As public attention and political debates across Europe have come to focus more and more on forced migration and on Italy's key role in the emergent humanitarian crisis in the Mediterranean, these issues are no longer a matter of specialist interest: not only aid agencies and other charities, but also many artists and arts organisations have sought to support refugees and asylum seekers. Scholars of different disciplines have similarly paid increased attention to mass migration, human trafficking and the experiences of forcibly displaced people across the Mediterranean, and specifically to the Italian context. ${ }^{25}$ This has obviously shaped and transformed discussions within Italian Studies, but it has also, we suggest, contributed to a wider and increasing interest in our field, which has coincided, perhaps not incidentally, with some leading British scholars of modern and contemporary Italy playing a significant role in the wider effort to re-think the role of Modern Languages, in the Twenty-First Century, in a transnational

\footnotetext{
${ }^{22}$ Attention to transnational perspectives was apparent at the most recent SIS Interim Conference 2014 Interstitial Italy: Reassessing Global Questions through the 'Peculiar' Italian Case, hosted in March 2014 by The British School at Rome, and organized in collaboration with the University of Warwick.

${ }^{23}$ See Theo D'haen, David Damrosch, and Djelal Kadir, eds, The Routledge Companion to World Literature (London; New York: Routledge, 2012); David Damrosch, ed., World Literature in Theory (Oxford: Wiley Blackwell, 2014).

${ }^{24}$ See, for instance, Lucia Boldrini, 'Comparative Literature in the Twenty-First Century: A View from Europe and the UK', Comparative Critical Studies, 3.1-2 (2006), 13-23; Loredana Polezzi, 'La mobilità come modello: ripensando i margini della scrittura italiana', Studi (e testi) italiani, 22 (2008), 115-28; Norma Bouchard 'Reading the Discourse of Multicultural Italy: Promises and Challenges of Transnational Italy in an Era of Global Migration', Italian Culture, 28.2 (September 2010), 104-20.

${ }^{25}$ See, for example, Federica Mazzara, 'Spaces of Visibility for the Migrants of Lampedusa: The Counter Narrative of the Aesthetic Discourse', Italian Studies, 70.4 (2015), 449-64, and 'Subverting the Narrative of the Lampedusa Borderscape”, Crossings: Journal of Migration \& Culture, 7.2 (2016), 135-47; Rutvica Andrijasevic, and Nicola Mai, eds, Trafficking (in) Representations. Special Issue, Anti-Trafficking Review, 7 (2016).
} 
context. ${ }^{26}$ With regard to literary studies, discussions about curricular development are consequently no longer focused on the future of the national literary canon, but reflect a more comprehensive notion of culture, and a greater interest in the relation between the arts. ${ }^{27}$ While debates in the UK have focused, for over a decade, on the advent of cultural studies - with Forgacs' and Lumley's aforementioned Italian Cultural Studies: An Introduction (1996) acting as a symbolic watershed, and, for some, a bone of contention - continental italianistica has more recently witnessed a surge of interest in world literature or 'letteratura globale'. ${ }^{28}$ As our project indicates, both trends are driven by a more general shift away from established disciplines and hierarchies of knowledge, and by a growing interest in multidisciplinary approaches. Indeed, theories of transnationalism - in comparative literature and, more generally, across the arts and humanities - tend to foreground what Steven Vertovek has described as 'fluidity of constructed styles and practices: syncretism, creolization, bricolage, cultural translation and hybridity', thus echoing a desire for multiplicity and complexity, which is also central to interdisciplinary approaches. ${ }^{29}$ Moreover, as Emma Bond has recently pointed out, metaphors of boundary-crossing and hyphenated identities - more commonly explored and employed in the study of sexuality and gender - may be fruitfully applied to phenomena of cultural globalization, with the hyphen in terms such as "trans-gender" becoming equally applicable to ideas of the 'trans-national'. ${ }^{30}$ Indeed, attention to the dialectic relation between place and perspective - highlighted by Bond as the twin poles of her hyphenated 'trans-national' - mark

\footnotetext{
${ }^{26}$ The large AHRC-funded Transnationalizing Modern Languages project, led by Charles Burdett, Jennifer Burns, Derek Duncan, Margaret Hills de Zàrate and Loredana Polezzi, is of seminal importance in this context. Other influential initiatives include the Cultures on the Move: Italy and the USA conference, organised by Guido Bonsaver and Matthew Reza and hosted by the University of Oxford in September 2016, and the forthcoming edited volume Colonial, Postcolonial and Transnational Encounters: Italy and the Horn of Africa edited by Simone Brioni and Shimelis Bonsa Gulema, and published by Peter Lang. An important strand of the large, ERC-funded research project Multilingual Locals and Significant Geographies: For a New Approach to World Literature led by Francesca Orsini and hosted by the SOAS Centre for Cultural, Literary and Postcolonial Studies (CCLPS) also focuses on the Horn of Africa.

${ }^{27}$ In Italy, turn-of-the-century debates about the national curriculum focused on anthologies and large editorial initiatives ('grandi opere') but little explicit attention was paid to canon formation as a theoretical and political process. For an interesting exception, see Ugo M. Olivieri,ed., Un canone per il terzo millennio: testi e problemi per lo studio del Novecento tra teoria della letteratura, antropologia e storia (Milan: Mondadori, 2001).

${ }^{28}$ See Armando Gnisci, Franca Sinopoli, and Nora Moll, La letteratura del mondo nel XXI secolo (Milan: Mondadori, 2010); Vittorio Coletti, Romanzo mondo: La letteratura nel villaggio globale (Bologna: Il Mulino, 2011); Giuliana Benvenuti and Remo Ceserani, La letteratura nell'età globale (Bologna: il Mulino, 2012); Rosanna Morace, Letteraturamondo italiana (Pisa: Edizioni ETS, 2012).

${ }^{29}$ Steven Vertovec, Transnationalism (London; New York: Routledge, 2009), p. 3.

${ }^{30}$ Emma Bond, 'Towards a Trans-National Turn in Italian Studies?', Italian Studies, 69.3 (2014), 415-24.
} 
many recent approaches to multi- and interdisciplinary inquiry, from Mieke Bal's theory of travelling concepts, to Emily Apter's considerations on (un)translatability, and Wendy Brown's recent work on national boundaries and global connectedness, while related ideas of translation have also emerged, beyond their linguistic origin, as a powerful metaphor for cultural and artistic exchange. ${ }^{31}$ Each of these approaches, in fact, encompasses a sense of flow and flexibility that also characterizes Bond's idea of the 'trans-national' and its hypothetical, similarly hyphenated counterpart, the 'trans-disciplinary'. Italian Studies, it appears, is emerging as a particularly apt context for such approaches, not only because of Italy's exposure to vast, intersecting migratory movements, but also because of what Bond describes as the country's 'peripheral status within Europe', and what she sees as a 'hyphenated "trans-" or in-between space', capable of 'queering' fixed notions of a national sovereignty and cultural hegemony. ${ }^{32}$

\section{Learning from Interdisciplinary Italian Cultural Practice}

Despite recent developments in cultural, visual and comparative studies - which all intersect with and sometimes sit within current iterations of the field of Italian Studies - as we stated at the beginning of this article, our practice as scholars, while changing, still lags behind the interdisciplinary, or perhaps more correctly, interartistic experimentation that Italy has been developing since 1900. In this section, we therefore sketch three key moments in the development of interdisciplinary practice in the Italian arts in order to foreground what we perceive as a continuing resistence to certain aspects of interartistic and interdisciplinary analysis even in those cases when the objects of study themselves call openly for a reconceptualisation of disciplinary boundaries. These twentieth-century and twenty-first century moments

\footnotetext{
${ }^{31}$ Mieke Bal, Travelling Concepts in the Humanities: A Rough Guide (Toronto: University of Toronto Press, 2002); Emily Apter, Against World Literature: On the Politics of Untranslatability (New York and London: Verso, 2013); Wendy Brown, Walled States, Waning Sovereignty Paperback (New York: Zone Books, 2014). On translation as a cultural metaphor, see especially Michael Cronin, Translation and Identity (London and New York: Routledge, 2006) and Translation in the Digital Age (London and New York: Routledge, 2012).

32 Bond, 'Towards a Trans-National Turn', p. 417. On the cultural significance of migration, see especially Donna Gabaccia, Italy's Many Diasporas (Seattle: University of Washington Press, 2000); Graziella Parati, Migration Italy: The Art of Talking Back in a Destination Culture (Toronto: Toronto University Press, 2006); Enrico Pugliese L'Italia tra migrazioni internazionali e migrazioni interne (Bologna: II Mulino, 2006).
} 
are, firstly, Futurism, then, the early postmodernism of Italy's neoavanguardia and, finally, the recent rise of intermedial and transmedial practice through digital technologies. While these three moments are by no means the only points at which interdisciplinarity, and especially interartistic practice, stepped into the foreground in Italy, our project identified these are the Italy's most striking case studies.

Whilst Futurism's engagement with the concept of opera d'arte totale in both theory and practice is well known, ${ }^{33}$ as Günter Berghaus pointed out, in the field of Futurism Studies there is still a strong compartmentalisation in terms of media and national boundaries. ${ }^{34}$ Overall scholarly interest tends to fall within the confines of media borders rather than on the interstices or boundary crossing between media and disciplinary and artistic practices; the result is at best multidisciplinary, but rarely interdisciplinary. ${ }^{35}$ The number of prominent exhibitions devoted to the movement-the centenary acted as an obvious catalyst for curatorial interest-partially redressed this tendency by including book and graphic design, showing particular attention to the manifestos in their theoretical complexity but also in their design features. $^{36}$

If one were to shift the terminological focus away from Futurist art to the field of design broadly conceived as the common denominator of a variety of artistic manifestations within the Futurist movement, the discrepancy between areas of research which are established fields within Futurist Studies-e.g. architecture and theatre, with the partial inclusion of set design - and those that continue to be marginal is clearly noticeable. Futurist fashion is a particularly interesting standpoint to reflect upon the potential for

\footnotetext{
${ }^{33}$ Vivien Greene, 'The Opera d'Arte Totale', in Italian Futurism 1909-1944, ed. by V. Greene, cat. of the exhibition (New York: Guggenheim Museum, 2013), pp. 210-13.

${ }^{34} \mathrm{G}$. Berghaus, 'Editorial: Aims and Functions of the International Yearbook of Futurism Studies', in International Yearbook of Futurism Studies, ed. by G. Berghaus, 1 (Berlin: de Gruyter, 2011), ix-xiii (p. ix). On the veritable explosion of texts on Futurism in the new millennium see Elza Adamovicz and Simona Storchi, 'Introduction', Back to the Futurists: The Avant-Garde and its Legacy, ed. by E. Adamovicz and S. Storchi (Manchester: Manchester University Press, 2013), pp. 1-13.

35 It is more common to find a focus away from stricter disciplinary and media boundaries in studies which do not focus solely of Futurism but frame the movement in term of the early history of multimediality. See for instance G. Celant and G. Maraniello, Vertigo: A Century of Multimedia Art from Futurism to the Web (Milan: Skira, 2008).

${ }^{36}$ The 2013 exhibition at the Guggenheim museum in New York strove to capture the interdisciplinary complexity of Futurism both in the early years of the movement and in the interwar years which saw some of the most theoretically rich experimentation in the field of the performing arts and design.
} 
interdisciplinary research and the resistance of traditionally conceived disciplines to the study of aspects of visual culture that fall outside the scholarly confines of the fine and decorative arts. ${ }^{37}$ The first postwar exhibition to focus on Futurism and fashion, with its close textual analysis of the manifestos and impressive range of textiles, textile design and garments, showed the centrality of dress for the Futurists and the clear theoretical articulation of fashion as art as early as $1914 .{ }^{38}$ In the manifesto Vestito antineutrale, published in September 1914, the potential for a political reading of dress is linked to the campaign for Italy's intervention but later manifestos also place emphasis on the transformative power of fashion which has the potential to turn the individual into 'un vero complesso plastico vivente'(Crispolti, p. 115). Experimentation in textile design married new design solutions, ${ }^{39}$ resulting in the close proximity between the fields of fashion, architecture, design, and performance: fashion had for the Futurists the potential to transform the body into the ultimate performative site, a living piece of sculpture or architecture, displaying an extraordinary synergy between textile design and painting. ${ }^{40}$ Giacomo Balla's designs for textiles, rugs, clothing, and lighting design, when viewed alongside his painting, testify to the allencompassing and interartistic impulse of the Futurist reconstruction of the universe which placed design above the fine arts as the supra-discipline able to cut across the artificial and obsolete distinction between media and artistic boundaries in both theory and practice..$^{41}$

\footnotetext{
${ }^{37}$ On the broader issue of the status of the study of fashion see Christopher Breward, 'Fashion Cultures Revisited. Between the Museum and the Academy. Fashion Research and its Constituencies', Fashion Theory, 12.1 (2008) 83-93. ${ }^{38}$ Enrico Crispolti, ed., I/ Futurismo e la moda, cat. of the exhibition (Milan: Padiglione d'Arte Contemporanea, 1988). The Manifesto della moda femminile futurista, by Volt, published in the journal Roma Futurista, 29 February 1920, argues against the artificial difference between art and fashion: 'un grande poeta o un grande pittore dovranno assumere l'alta direzione di tutte le grandi case di moda femminili. La moda è un'arte come l'architettura e come la musica', in Crispolti, Il Futurismo e la moda, p. 115.

${ }^{39}$ The 'tuta', Thayaht's new Futurist garment, is a particularly interesting example of the radical formal solutions presented by the Futurists. See Crispolti, 'Thayhat, la "tuta”, le stoffe, i figurini e il manifesto del 1932 con Ram', in II futurismo e la moda, pp. 131-37.

40 Balla's textile designs executed between 1925-30 or Tullio Crali's designs for womenswear sent to Benedetta Marinetti and to Balla's daughters, Luce and Elica, in 1931 are a striking example of the way in which the static quality of painting finds in the physical fluidity of fabric a truer embodiment of the principle of dynamism which underpins much of Futurist theory and practice. For Balla see Crispolti, II Futurismo e la moda, cat. entries no. 14-19, 20-28, and 29-37; for Crali, see cat. entries no. 140-49. See also Eugenia Paulicelli, 'Fashion and Futurism: Performing Dress', Annali d'Italianistica, 27 (2009), 187-208.

${ }^{41}$ A more integrated vision of Futurist design informed the exhibition: Futurismo, moda, design: la ricostruzione futurista dell'universo quotidiano, cat. of the exhibition, (Gorizia: Musei Provinciali Borgo Castelli, 2009-2010).
} 


\section{Postmodernism}

Similarly to Futurist experimentation, the poetics and cultural practice of postmodernism entail a deep commitment to interartistic creativity. The unique cultural atmosphere of North America's and Western Europe's 'long Seventies' is best understood, in Steven Connor's words, as 'a complex simultaneity, a coincidence of different lines of development, in architecture, art, literature, film, popular culture and so on' ${ }^{42}$ It is surprising, then, that much scholarly work on postmodernism has remained firmly grounded in disciplinary categories, paying little attention to the creative exchange between forms and media, or to the general social and psychological dynamics of interartistic creativity. In Italy, controversies about canonization and periodization have dominated intellectual discussion, and much thought has been given to the distinction - first sketched by Frederic Jameson and subsequently developed by Romano Luperini and, more recently, by Raffaele Donnarumma - between postmodernity (a historical period, now widely assumed, in general agreement with Remo Ceserani, to date back to the Fifties) and postmodernism (a primarily cultural notion, defined by its inherent relationship to modernism). ${ }^{43}$ Attitudes towards the two phenomena differ significantly: while "postmodernism" remains a contested term, especially in Italy, most scholars in Italian Studies appear to have embraced the notion of postmodernity as originally defined by the British anthropologist and geographer David Harvey: an epoch in which advanced societies - particularly in the West - experienced a series of profound transformations associated with de-industrialization and the rapid growth of service and hi-tech sectors; globalization on an economic, social, ecological, technical and communicative level; the rise of new media and communication technologies; the transformation of cognitive and pedagogical processes and aesthetic preferences; a wider circulation of works of art as commodities; a more dynamic interaction between cultural centres and peripheries. ${ }^{44}$ Despite this consensus, little attention has been paid to the complex interplay of these wider trends, especially in Italy, or to their influence on Italian

\footnotetext{
${ }^{42}$ Steven Connor, Postmodernist Culture: An Introduction to Theories of the Contemporary, 2nd edn (Oxford: Blackwell, 1997), p. vii.

${ }^{43}$ See Fredric Jameson, Postmodernism or The Cultural Logic of Late Capitalism (London: Verso, 1991); Remo Ceserani, Raccontare il postmoderno (Turin: Bollati Boringhieri, 1997), pp. 120-24; Romano Luperini, Controtempo (Napoli: Liguori, 1999), pp. 169-78; Raffaele Donnarumma, Ipermodernità: dove va la narrativa contemporanea (Bologna: II Mulino, 2014), pp. 25-31. For an overview of the Italian response to postmodernism, see Monica Jansen, II dibattito sul postmoderno in Italia: in bilico tra dialettica e ambiguità (Florence: Cesati, 2002).

${ }^{44}$ David Harvey, The Condition of Postmodernity: An Enquiry into the Origins of Cultural Change (Oxford: Blackwell, 1990).
} 
artistic production during the Sixties and Seventies. Since the beginning of the twenty-first century, polemics about the presumed death or long afterlife of postmodernism have drawn a welcome, but perhaps disproportionate attention to our cultural present. ${ }^{45}$ Meanwhile, research on earlier decades has stagnated, with influential works of secondary literature re-proposing established analytic tools and a rather

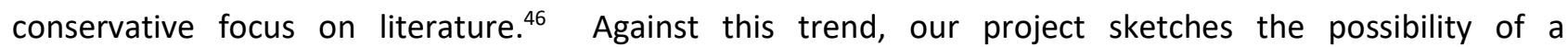
multidisciplinary and open-ended reading of Italian art and culture of the Sixties and Seventies. There is scope, we suggest, for a new history of the period, which relates the experiences of neoavanguardia and early postmodernism to contemporaneous developments in the areas of photography, architecture, fashion and design, and which pays greater attention to underexplored links between literature, music and the visual arts. ${ }^{47} \mathrm{An}$ interdisciplinary approach, we propose, also serves to highlight the influence of creative artists and thinkers like Enrico Baj, Nanni Balestrini, Luciano Berio, Umberto Eco, Piero Manzoni, Gastone Novelli, and Edoardo Sanguineti (to name but a few) who saw themselves as heirs to the cultural wealth of earlier avantgardes, and who expressed themselves in more than one medium. Our aim, then, is not to define the interartistic as a fixed canon of works, situated 'between' established media and art forms, but rather to embrace the open-endedness of experimental art and the post-war avant-gardes, to echo their critique of normative boundaries, their sense of freshness, confidence and iconoclastic zeal. Optimism and the demand for a radical renewal of the arts, are at the heart of works like Umberto Eco's influential Opera aperta (1962), a book that was adopted by Italy's neoavanguardia as its unofficial manifesto, and whose 'interdisciplinary' concerns range from experimental literature to informal painting, from Husserl to Heisenberg, and from nonEuclidean geometry to serial music, thus conveying a sense of intellectual excitement that was characteristic

\footnotetext{
${ }^{45}$ See Pierpaolo Antonello and Florian Mussgnug, eds, Postmodern Impegno: Ethics and Commitment in Contemporary Italian Culture (Oxford: Peter Lang, 2009).

${ }^{46}$ See Renato Barilli, La neoavanguardia italiana: dalla nascità del 'Verri' alla fine di 'Quindici' (Bologna: II Mulino, 1995); Francesco Muzzioli, II Gruppo 63: Istruzioni per la lettura (Rome: Odradek, 2013); Andrea Cortellessa, ed., 'Col senno di poi', in Gruppo 63: I/ romanzo sperimentale, ed. by Nanni Balestrini (Rome: L'orma editore, 2013), pp. 195424.

${ }^{47}$ Our third workshop 'Interdisciplinary Postmodernism: Re-Thinking the Sixties', held at UCL in May 2013, included contributions on photography, performance art, fashion and design by Martina Caruso (Courtauld), Robert Lumley (UCL), Catharine Rossi (Kingston), Sonnet Stanfill (V\&A), as well as papers on literature and philosophy by Pierpaolo Antonello (Cambridge) and Raffaele Donnarumma (Pisa). Steve Halfyard (Birmingham Conservatoire) contributed with a presentation on Umberto Eco and Luciano Berio, as well as a rare live performance of Berio's Sequenza III for female voice (1965).
} 
of many artistic circles of the period. Eco's artistic and intellectual 'experiments' are also indicative of the variety and diversity of individual approaches to 'theory', which our project envisages as a constantly changing, dynamic field of self-reflective investigation. By foregrounding the practitioners' perspective, then, we intend to reformulate the interartistic as an approach or a problem, emphasizing the need for collective work, which reflects the simultaneous, incommensurate presence of different theories and disciplinary fields.

\section{Transmedia and the digital age}

According to David Forgacs, in an article that predated by some five years Henry Jenkin's much-cited Convergence Culture, ${ }^{48}$ the next significant step in relation to the convergence of the arts occurred in Italy, and elsewhere, in the 1990s. This next step is predicated on the digitalisation of artistic media and their circulation across the Internet. ${ }^{49}$ Forgacs' sociological analysis posits a shift from the segmented national media system in Italy (print, film and broadcasting) to what he sees as a triple convergence of media in terms of: technology (in which 'text, sounds and pictures (still and moving images) can all be encoded as computer readable information'), economy (mergers and synergies in the media economy) and consumption (audiences can now receive media that were once distinct in the same place).

The Internet, building on interdisciplinary and interartistic advances on the part of cinema and television across the twentieth century, takes the interaction and intermingling of the arts further. These convergences are experienced not just as a normal part of the lived experience of mass culture, facilitated by the emergence of the Internet, but are also the subject of experimentation on the part of elite or semielite artists in Italy, such Wu Ming and Scrittura Industriale Collettiva. The effect of the Internet on storytelling has been theorised both by the artists themselves and, internationally, in universities, where discussions of transmedia, and specifically transmedial storytelling, has taken hold. Theorists have begun looking at narrative interaction, multimodality, the remediation of genres across media, as well as

\footnotetext{
${ }^{48}$ Henry James, Convergence Culture: Where Old and New Media Collide (New York: NYU, 2006).

${ }^{49}$ David Forgacs, 'Scenarios for the Digital Age: Convergence, Personalization, Exclusion', Modern Italy, 6.2 (2001), 129-39.
} 
reassessing authorship (including co-creation and fan fiction) and the reception and participation of audiences. However, this emerging research has been focused in large part on international media and work on Italy remains limited. Some publications, such as Bazzichelli's, Networking: la rete come arte (2006), Boscolo's edited volume Overcoming Postmodernism: The Debate on New Italian Epic (2010) and Brook and Patti's Transmedia: Storia, memoria e narrazioni attraverso i media $(2015),{ }^{50}$ go some way to addressing the poverty of research on the Italian experience. However, given the revolution in interartistic and interdisciplinary practice that has emerged with digital technology, this research must be considered very limited. Moreover, what research now exists stems largely from the study of the novel and leaves Italian Studies with significant questions about the interdisciplinary transformations to other Italian arts, such as music, the visual arts and cinema, which have all been profoundly altered by interartistic and interdisciplinary practice during the Internet age.

\section{Conclusion. Towards a methodology of interdisciplinary practice}

Italo Calvino famously lamented the 'unending rainfall of images' to which we are subjected. ${ }^{51}$ Failing to elect these as our object of study and to develop a critical discourse that allows us, not only to study the images themselves but the way they intersect with other cultural objects, risks marginalising our discipline in the new millennium. What we should be doing instead is reclaiming the interrelatedness of Italian visual and literary culture, and to view both as central to a wider cultural field, which includes music, architecture, design, and the creative use of new media. Italian artists have, at least since the Renaissance, crossed artistic boundaries with great ease workings as a painters, sculptors, designers, architects, poets, musicians, writers on art, literature and society as well as often crossing the artistic boundaries to engage in wideranging interdisciplinary activities (artists could be engineers or natural scientists).

\footnotetext{
50 Tatiana Bazzichelli, Networking: la rete come arte (Milan: Costa e Nolan, 2006); Claudia Boscolo, ed., Overcoming Postmodernism: The Debate on the New Italian Epic. Special Issue, Journal of Romance Studies, 10.1 (2010); Clodagh Brook, and Emanuela Patti, eds, Transmedia: storia, memoria e narrazioni attraverso i media (Milan: Mimesis, 2015). 51 Italo Calvino, 'Exactitude', in Six memos for the Next Millennium (New York: Vintage Books, 1993), p.57.
} 
These observations are not a call for arms in favour of the uncritical adoption of new disciplinary fields. As James Elkins noted, 'the existence of texts that depend on disciplinary purity is itself crucial for the possibility of a truly innovative interdisciplinarity'. ${ }^{52}$ The adoption, or lack thereof, of new disciplinary fields relates to the dangers of de-skilling that often accompany the relaxation of disciplinary boundaries, but do also call into question the selection of the objects of study and a degree of conservatism that keeps at bay the study of objects of Italian culture which are strongly associated with Italy's modernisation and that could/should be better placed to engage in a constructive dialogue with scholars of twentieth- and twentyfirst-century culture. In the same article mentioned above, Elkins borrowed a metaphor from Giacomo Leopardi who defined his scholarship as 'peregrine'. Elkins observes that the peregrine falcon has two maculas in the eye: one for focusing forward and one for sharp-eyed looking to either side. Scholarship allows for both visions and interdisciplinarity need not interfere with disciplinary expertise.

52 James Elkins, 'Nine Modes of Interdisciplinarity in Visual Studies', JVC, 2.2 (2003) 232-37, (p. 235). 